\title{
Transitional Justice and the Constitutional Crisis: The Case of Poland (2015-2019)
}

\section{Introduction}

During the last four years the situation in Poland was a matter of interest to the worldwide legal community mostly due to the constitutional crisis. Its focal point were the relations between the government and the judiciary, mainly the Constitutional Tribunal (CT) and the Supreme Court (SC). Yet, the years 2015-2019 were also a time of a revival of transitional justice measures, such as cleansing the public sphere of communist symbols, remodelling of lustration legislation, and further reduction of pensions of communist secret service employees and officers. As parts of these provisions were either ambiguous or debatable from a constitutional point of view, the controversies were resolved primarily in administrative and ordinary courts.

In this paper I argue that these spheres are interconnected and that Poland's constitutional crisis has a transitional justice dimension. In order to prove it, I start with an overview of retrospective instruments dealing with the communist past, which were introduced in the last four years. I concentrate on their collective character and on politics of memory that they represent. Next, I turn to the constitutional crisis itself, discussing its possible explanations. Here, I use government bills, statements of purpose, and public speeches by members and supporters of the current administration to present the transitional justice aspect of the crisis. As the sincerity of the government's motives is often questioned in Poland, in the fourth part I use the criteria offered by the Rawlsian public reason to present conditions under which these actions can be considered genuine as well as arguments supporting such an interpretation. In the end I claim that the dramatic constitutional backsliding that Poland has recently experienced can be explained not only as a power grab, but also as a result of tension between the rule of law and the principle of individual responsibility, on one hand, and the resort to collective accountability in the desire to fulfil what the government sees as justice, on the other. 


\section{Polish transitional justice initiatives (2015-2019)}

In the wake of the 1989 political transformation Poland has adopted a fair amount of transitional justice measures. These included lustration, the establishment of the Institute of National Remembrance (Polish: Instytut Pamięci Narodowej, IPN), the dissolution of the Security Service (Polish: Stużba Bezpieczensstwa) of the Ministry of Internal Affairs, the opening of the archives of the communist security service, the reduction of pensions of its former employees, extensions of the periods of limitation for communist crimes, and a limited number of criminal proceedings ${ }^{2}$. However, many of these mechanisms were perceived as lenient or protracted. Thus, after the Law and Justice (Polish: Prawo i Sprawiedliwość) party gained parliamentary majority in 2015, it introduced new transitional justice instruments. In this section, I provide an overview of the most important initiatives related to the communist past ${ }^{3}$.

\subsection{Cleansing public spaces of communist symbols}

After a period of political transition, symbols of authoritarian rule tend to linger in the public space as a powerful memento of the painful past. Newly established democracies often decide to eliminate such reminders by renaming streets, removing monuments, and transforming museums ${ }^{4}$. Even though such initiatives were present in Poland after 1989, it was not until 2016 that an official law regulating the process was passed. According to the Prohibition of the Promotion of Communism Act ${ }^{5}$, the names of localities, streets, roads, bridges, squares, buildings and facilities (including health institutions and schools) cannot commemorate communism or any other totalitarian system with surnames, dates or other names which symbolise such a regime, or promote it otherwise. In case of such names, local governments had been obliged to change

2 For an overview of Polish transitional justice experience see e.g.: B. Banaszkiewicz, Rozrachunek z przesztościa komunistycznq w polskim ustawodawstwie i orzecznictwie Trybunatu Konstytucyjnego [Eng. Reckoning with Communist Past in Polish Legislation and Judgments of the Constitutional Tribunal], "Ius et Lex" 2003/1, pp. 441-486; A. Czarnota, The Politics of the Lustration Law in Poland, 1989-2006, in: A. Mayer-Rieckh, P. de Greiff (eds.), Justice as Prevention: Vetting Public Employees in Transitional Societies, New York 2007, pp. 222-258; M. Krotoszyński, Modele sprawiedliwości tranzycyjnej [Eng. Models of Transitional Justice], Poznań 2017, pp. 113-118, 139-142; A. Młynarska-Sobaczewska, Autorytet państwa. Legitymizacyjne znaczenie prawa w państwie transformacji ustrojowej [Eng. State Authority: A Legitimizing Significance of Law in the Country of Political Transformation], Torun 2010, pp. 267-271, 292-337, 355-371, 374-387, 394-408, 413-447; M. Nalepa, M. Krotoszyński, Poland, in: L. Stan, N. Nedelsky (eds.), Encyclopedia of Transitional Justice, Vol. 2, 2 ${ }^{\text {nd }}$ ed., Cambridge 2020 (forthcoming). For more on transitional justice in general see e.g.: J. Elster, Closing the Books: Transitional Justice in Historical Perspective, Cambridge 2004; C. Murphy, The Conceptual Foundations of Transitional Justice, Cambridge 2017; R. Teitel, Transitional Justice, New York 2000.

3 Due to the scope of the paper I leave aside the controversial - and quickly repealed - 2018 memory law, penalizing public and unfounded allegations that the Polish nation or state were responsible or co-responsible for the Holocaust or other crimes under international law. See e.g.: M. Małecki, P. Mikuli, The New Polish 'Memory Law': A Short Critical Analysis, "DPCE Online" 2018/1, pp. 279-284; T.T. Koncewicz, On the Politics of Resentment, Mis-memory, and Constitutional Fidelity: The Demise of the Polish Overlapping Consensus?, in: U. Belavusau, A. Gliszczyńska-Grabias (eds.), Law and Memory: Towards Legal Governance of History, Cambridge 2017, pp. 263-290.

4 See e.g.: J. Barsalou, V. Baxter, The Urge to Remember. The Role of Memorials in Social Reconstruction and Transitional Justice, Washington 2007, https://www.usip.org/sites/default/files/srs5.pdf, accessed on: 26 November 2019; D. Light, C. Young, Public Memory, Commemoration, and Transitional Justice: Reconfiguring the Past in Public Space, in: L. Stan, N. Nedelsky (eds.), Post-Communist Transitional Justice. Lessons from Twenty-Five Years of Experience, New York 2015, pp. 233-251.

5 Full name: Act of 1 April 2016 on the Prohibition of Promotion of Communism and Other Totalitarian Systems Through the Names of Buildings, Localities, Facilities, and Through Monuments (Polish title: Ustawa z 1.04.2016 r. o zakazie propagowania komunizmu lub innego ustroju totalitarnego przez nazwy jednostek organizacyjnych, jednostek pomocniczych gminy, budowli, obiektów i urządzeń użyteczności publicznej oraz pomniki, tekst jedn.: Dz. U. z 2018 r. poz. 1103). 
them within a year of the law's entry into force. Should a local council fail to do so, the voivode (province governor, representative of the government in the region) was to provide a new name within the next three months. The monuments commemorating or promoting totalitarian systems were prohibited as well, and the law gave voivodes the right to order their removal. In both cases, before a voivode could make a decision, they were obliged to seek an opinion of the IPN on whether a name or a monument were to change or be removed ${ }^{6}$.

The voivodes and the IPN were often in disagreement with local councils as to whether a name promoted or celebrated communism. Frequently, a name which a local council believed not to be covered by the law, was perceived as a communist symbol by the relevant voivode and the IPN, the latter having even prepared a list of almost 150 names destined to change ${ }^{7}$. For example, there were controversies around street names commemorating dates on which a city, a town or a village was, depending on the perspective, freed from the Nazi rule or captured by the advancing communist Red Army. In these and other cases many local communities appealed the voivodes' decisions. Thus, in the end it was the courts that had to decide how to assess whether a name commemorated or promoted communism. Although the judgments were not always coherent, two main lines of reasoning can be distinguished. According to the first one, a name celebrates communism if it is proven that in public perception, and especially in the perception of the members of local community, it is indeed a widely recognizable symbol of communism ${ }^{8}$ (which is rather uncommon today). In other cases, notably in those where the streets were renamed in recent years, the administrative courts concentrated on the intentions of local councils ${ }^{9}$. Thus, contrary to the government's plan of a broad cleansing with little attention to regional specificities, in majority of cases the courts sided with local councils, resulting in a more restricted, nuanced, and individualized scope of the law.

\subsection{The reduction of pensions}

The pensions of former communist security service officers were first reduced in 2009 by the coalition government of the Civic Platform (Polish: Platforma Obywatelska) and the Polish People's Party (Polish: Polskie Stronnictwo Ludowe). The law, which lowered the coefficient used for the calculation of pensions from $2.6 \%$ to $0.7 \%$ for each year of service in communist security agencies was upheld by the $\mathrm{CT}^{10}$. Later, the European Court of Human Rights (ECtHR) decided that the statute did not violate the

6 For more on the law see e.g.: A. Wójcik, U. Belavusau, Renaming Streets - A Key Element of Identity Politics, "New Eastern Europe" 2018/3-4, pp. 161-166.

7 The list is available at: https://ipn.gov.pl/pl/upamietnianie/dekomunizacja/zmiany-nazw-ulic/nazwy-ulic/nazwy-dozmiany, accessed on: 21 April 2020.

8 See e.g.: judgment of the Voivodship Administrative Court (VAC) in Gdańsk of 29 March 2018 (III SA/Gd 127/18), LEX No. 2473340; judgment of the VAC in Poznań of 14 November 2018 (IV SA/Po 752/18), LEX No. 2584695; judgment of the Supreme Administrative Court (SAC) of 20 March 2019 (II OSK 3391/18), LEX No. 2649599.

9 In some of the more bizarre cases, the courts used this argument to uphold resolutions in which local councils gave the streets same names as before, albeit officially for different reasons. For example, one of the main streets in Piła commemorated $14^{\text {th }}$ of February, the day when the city was conquered by the Soviet Army. In 2017 the city council "changed" the name of the street to $14^{\text {th }}$ of February, allegedly to commemorate the Valentine's Day. Judgment of the SAC of 20 March 2019 (II OSK 3413/18), LEX No. 2646665. See also: judgment of the SAC of 14 February 2018 (II OSK 254/18), LEX No. 2486428.

10 Judgment of the CT of 24 February 2010 (K 6/09), OTK-A 2010/2, item 15. The judgment was highly controversial with five of fourteen $\mathrm{CT}$ judges dissenting on the merits. 
European Convention on Human Rights ${ }^{11}$. Both courts regarded the law as a legitimate and socially just means to put an end to unfairly acquired privileges. As the average pension of an officer was still higher than the average ordinary pension, the law was not found disproportionate either.

The 2016 amendment to the 1994 Uniformed Services Pensions Act ${ }^{12}$ went much further. The law significantly widened the list of communist security service agencies. Some of the additions seemed rather problematic ${ }^{13}$. What is more, for each year of service in communist security agencies the coefficient mentioned above was reduced to $0 \%$. If a person falls under the new provisions, the pension received cannot be higher than the average one, even if the period of service in communist agencies was short and the person later served in democratic Poland as well. This circumstance can only be a basis for a decision of the Minister of Internal Affairs to exclude such a person from the scope of the law (Article 8a); yet, so far, this option has rarely been used ${ }^{14}$. The reduction of pensions does not involve former officers and employees who can prove that they secretly and actively supported opposition movements before 1990 (which is rarely possible more than 30 years after the transition). However, if no exception applies, the reduction also affects disability pensions and pensions for the families of deceased officers ${ }^{15}$. Thus, apart from the two unlikely exceptions noted above, the law is based on collective responsibility, as it applies to former communist security service employees and their families regardless of the length and character of their service ${ }^{16}$.

The government presented the changes as a necessary mechanism promoting elementary social justice ${ }^{17}$. Yet, courts have so far been reluctant to apply the law. Being doubtful of the constitutionality of the provisions, the Warsaw District Court (Polish: Sad Okregowy) decided in 2018 and 2019 to suspend two appeals against decisions lowering the pensions and to refer the law to the $\mathrm{CT}^{18}$. The District Court in Częstochowa went even further: it found the law in contradiction of Articles 2, 3, 4(3) and 6 of the Treaty on European Union ${ }^{19}$, refused to apply it, and ordered the restoration of the former amount of pension. The court not only criticised the statute for applying

11 Decision of the ECtHR of 14 May 2003, Cichopek and Others v. Poland (15189/10).

12 Official name: Act of 18 February 1994 on the Pensions of the Officers of the Police, the Internal Security Agency, the Foreign Intelligence Agency, the Military Counterintelligence Service, the Military Intelligence Service, the Central Anti-Corruption Bureau, the Border Guard, the State Protection Service, the State Fire Service, the Customs and Treasury Service, the Prison Service and their Families (Polish title: Ustawa z 18.02.1994 r. o zaopatrzeniu emerytalnym funkcjonariuszy Policji, Agencji Bezpieczeństwa Wewnętrznego, Agencji Wywiadu, Służby Kontrwywiadu Wojskowego, Służby Wywiadu Wojskowego, Centralnego Biura Antykorupcyjnego, Straży Granicznej, Służby Ochrony Państwa, Państwowej Straży Pożarnej, Służby Celno-Skarbowej i Służby Więziennej oraz ich rodzin, tekst jedn.: Dz. U. z 2019 r. poz. 288 ze zm.).

13 For instance, the list includes: Foreigners' Registration Bureau, National Identification Number Department (Polish: Departament PESEL), and the Inspectorate for Operational Protection of the Żarnowiec Nuclear Power Plant.

14 As of 11 December 2019 out of 4869 motions to the Ministry of Internal Affairs, less than half (2143) were decided and only 38 were approved. Letter of 11 December 2019 from the Ministry of Internal Affairs, No. DBI-WODO-0667-3-279/2019 (on file with author). Many negative decisions were overturned by administrative courts. See e.g. judgment of the VAC in Warsaw of 19 March 2019 (II SA/Wa 2262/18), LEX No. 2642960.

15 Articles 8a, 13b, 13c, 15c, 22a and 24a of the Uniformed Services Pensions Act.

16 For more on the pension reduction provisions see: M. Grabarczyk, Uniformed Services Pension Amendment Acts in Poland as a Part of State Politics of Memory, "Archiwum Filozofii Prawa i Filozofii Społecznej” 2019/3, pp. 67-80.

17 See: speech by Minister of Internal Affairs and Administration Mariusz Błaszczak: Sprawozdanie stenograficzne $z$ 31. posiedzenia Sejmu VIII kadencji [Eng. Minutes from 31. Session of 8th Term of Sejm], 2.12.2016, pp. 522-528, https://tinyurl.com/SejmVIII31, accessed on: 1 December 2019.

18 Decision of the Warsaw District Court of 24 January 2018, available at: https://tinyurl.com/TKP418, accessed on: 2 December 2019; decision of the Warsaw District Court of 27 May 2019, available at: https://inyurl.com/TKP1619, accessed on: 2 December 2019.

19 The Treaty on the European Union of 7 February 1992 (cons. version: OJEU C 202, 7.6.2016, p. 13). 
collective responsibility, but - in a vigorous sermon against legal assessment of the past - also stated that liberal democracy, being based on "the equality of values" required the court to be "ideologically neutral" and, therefore, forbids it to "evaluate history" or judge "past moral choices of citizens as either good or bad" $"$. The aforementioned cases are still pending, yet many other courts have also decided either to suspend the proceedings or to quash the decisions lowering the pensions. Finally, in December 2019 the SAC stated that Article 8a of the law requires the Minister of Internal Affairs to exclude an officer from the scope of the law if his/her actions had not fostered the goals of a totalitarian country in a direct way. Thus, the SAC reinterpreted the provisions of the law in light of the rule of law requirements, partly substituting collective responsibility with an individual one ${ }^{21}$.

\subsection{Lustration}

Unlike lustration provisions in the Czech Republic ${ }^{22}$, where certain categories of people were prohibited from holding public offices, Polish lustration - first introduced in 1997 - has, until recently, generally refrained from using retroactive administrative sanctions. Instead, it has relied on lustration statements. Thus, according to the Lustration $\mathrm{Act}^{23}$, a person who holds a public office or runs for it is required to provide a declaration on whether they had been an employee, an officer or a secret and conscious collaborator of the communist security service. If the statement is true, no sanctions are imposed. On the other hand, a lie in a lustration statement - established by a court in a trial based on the criminal procedure - results in a ban on holding public offices for a period from three to ten years ${ }^{24}$. Therefore, in general, Polish lustration can be considered a historical clarification mechanism, as the sanctions are imposed only on those unwilling to reveal the truth ${ }^{25}$.

Until recently, the only exception to this rule was that former employees, officers and collaborators of communist security service were prohibited from heading several security agencies or serving in the Central Anti-Corruption Bureau (Polish: Centralne Biuro Antykorupcyjne). Since 2015 this ban has been expanded to cover more than 30 posts, including SC judges, prosecutors, diplomats, directors of national institutes, members of governing bodies of public and private universities, candidates for professor's titles, and board members of hunting clubs and sports associations. This turn towards collective retribution seems to be informed by the belief that such actions are necessary for both moral and practical reasons. For example, the purge of diplomats with past links to communist secret service was presented as both a matter of social justice, and

20 Judgment of Częstochowa District Court of 31 May 2019 (IV U 241/19), LEX No. 2704111.

21 Judgment of the SAC of 13 December 2019 (I OSK 1464/19), LEX No. 2764720.

22 For the purpose of this paper I use the term "lustration" in a broad meaning, covering both provisions which forbid former officers, employees and collaborators of communist security agencies to hold certain public offices, and regulations which only require that these connections are revealed.

23 Official name: Act of 18 October 2006 on the Disclosure of Information on Documents of State Security Agencies from Years 1944-1990 and the Content of These Documents (Polish title: Ustawa z 18.10.2006 r. o ujawnianiu informacji o dokumentach organów bezpieczeństwa państwa z lat 1944-1990 oraz treści tych dokumentów, tekst jedn.: Dz. U. z 2019 r. poz. 430 ze zm.).

24 Penalties for members of legal professions are decided by disciplinary courts.

25 More on Polish lustration in: A. Czarnota, The Politics...; M. Krotoszyński, Polish Lustration and the Models of Transitional Justice, “Adam Mickiewicz University Law Review” 2014/3, pp. 199-211; A. Młynarska-Sobaczewska, Autorytet..., pp. 292-337; M. Ciobanu, M. Krotoszyński, Lustration Court (Poland), in: L. Stan, N. Nedelsky (eds.), Encyclopedia of Transitional Justice, Vol. 3, $2^{\text {nd }}$ ed., Cambridge 2020 (forthcoming). 
as a crucial step to ensure efficient operation of the foreign service and its patriotic attitude $^{26}$. In case of academics, the parliamentary majority presented the restrictions as a decommunization initiative aimed at a moral rebirth of Polish universities ${ }^{27}$.

These changes are constitutionally problematic for at least four reasons. Firstly, in 2007 the CT invalidated lustration in relation to people who could not be regarded as public figures: officials at private universities, all university professors, and board members of sports associations ${ }^{28}$. These posts are again covered by the law. Secondly, the introduction, 30 years after the transition, of restrictions on access to public offices and on engagement in the private sector is at best highly questionable from the perspective of the proportionality principle ${ }^{29}$. Thirdly, where the connections with the communist secret service are established based on the lustration statement entered before the amendment introducing sanctions came into force, the provisions seem to violate the principle of protection of the trust towards the state and its law ${ }^{30}$, especially as they lead to self-incrimination. Finally, the provisions in question require no individualized vetting: instead, the government opted for a general purge, banning all former communist security service employees, officers and collaborators from holding the abovementioned positions, regardless of whether their actions were in fact harmful or whether they were aimed against the opposition, churches or human rights movement at all.

\subsection{Parliamentary resolutions}

Non-binding parliamentary resolutions are often used to acknowledge and assess the past, as well as to promote official historical narratives. In the last 4 years, the Sejm, the lower chamber of the Polish Parliament, examined the communism and the pre-1989 period on multiple occasions. In 2017 the Sejm condemned the Bolshevik revolution and the communist ideology as "criminal", contrary to "basic values of humanity and traditions of European civilisation", and leading to "tragic social and economic outcomes". It also warned that "leftist revolts, even if glazed over with beautiful and lofty slogans, always bring about terror and crimes, and harm both individuals and society as a whole" 31 . Regarding December 1970 protests in northern Poland, the Sejm denounced the communist government as ruthless and willing to massacre those who opposed their degrading living conditions ${ }^{32}$. In other resolutions, the Sejm has praised individuals and

26 Poselski projekt ustawy o zmianie ustawy o stużbie zagranicznej oraz ustawy o ujawnianiu informacji o dokumentach organów bezpieczeństwa państwa z lat 1944-1990 oraz treści tych dokumentów. Druk nr 2992, VIII kadencja Sejmu [Eng. MPs' Bill to Amend Act on Foreign Service and Act on the Disclosure of Information on Documents of State Security Agencies from Years 1944-1990 and the Content of These Documents. Form No. 2992, 8th Term of Sejm], pp. 7-11, http:// www.sejm.gov.pl/sejm8.nsf/druk.xsp?nr=2992, accessed on: 1 December 2019.

27 See: speech by Joanna Borowiak MP (Law and Justice): Sprawozdanie stenograficzne z 62. posiedzenia Sejmu VIII kadencji [Eng. Minutes from 62. Session of 8th Term of Sejm], 9 May 2018, p. 224, https://tinyurl.com/SejmVIII62, accessed on: 1 December 2019.

28 Judgment of the CT of 11 May 2007 (K 2/07), OTK-A 2007/5, item 48.

29 See also: judgment of the ECtHR of 27 July 2004, Sidabras and Džiautas v. Lithuania (55480/00, 59330/00), paras. 57-58, 60; judgment of the ECtHR of 16 March 2006, Ždanoka v. Latvia (58278/00), paras. 132-135.

30 The principle is derived from Article 2 of the Constitution. The Constitution of the Republic of Poland of 2 April 1997 (Polish title: Konstytucja Rzeczypospolitej Polskiej z 2.04.1997 r., Dz. U. Nr 78, poz. 483 ze zm.).

31 Resolution of Polish Sejm of 24 November 2017 on the Condemnation of the Ideology and Outcomes of Bolshevik Revolution (Polish title: Uchwała Sejmu Rzeczypospolitej Polskiej z 24.11.2017 r. w sprawie potępienia ideologii i skutków rewolucji bolszewickiej, M.P. poz. 1114).

32 Resolution of Polish Sejm of 17 December 2015 on the Commemoration of the Victims of December 1970 (Polish title: Uchwała Sejmu Rzeczypospolitej Polskiej z 17.12.2015 r. w sprawie uczczenia pamięci ofiar Grudnia 1970 r., M.P. z 2016 r. poz. 6). 
organisations that opposed the communist rule, as well as paid tribute to its victims ${ }^{33}$. It also stated that the victims of the 1981 martial law "still await a just reckoning with the crimes [then committed]" ${ }^{4}$. Most of the resolutions were accepted either unanimously or by a large majority.

\subsection{Polish politics of memory (2015-2019): anti-communism and collective responsibility}

Since 2015 Polish politics of memory has been shaped by strong anti-communist beliefs shared by the government and a large majority of Polish MPs. These views were expressed not only in non-binding parliamentary resolutions, but they also resulted in a ban on communist symbols in the public sphere. The government also resorted to harsher measures, such as the reduction of pensions of communist security service officers and their families, and the remodelling of lustration laws to include retroactive administrative sanctions ${ }^{35}$. The rationale behind this change seems to be the belief that without these sanctions social justice could not be achieved. Yet, the instruments introduced by the government often resorted to collective responsibility. As a result, the emerging vision of the past does not leave much room for its alternate understandings. Thus, some claim that these delayed measures symbolically exclude those not sharing the government's view of the past and its vivid anti-communism from the national community, in turn endangering its very existence. As Tadeusz T. Koncewicz puts it:

the "politics of resentment" and "memory capture" push Poland towards a standstill and an identity crisis. With the "politics of resentment" and the exclusion of the Other, and with "memory capture" elevated to the status of a new mode of governance, the challenge of paddling together has never been more acute ${ }^{36}$.

As the measures introduced by the government were barely case-specific, it was court judgments that restricted the scope of the regulations and introduced a more individualized approach. Many of the decisions regarding street names were overturned as contrary to the public perception or the intensions of local councils, and numerous decisions refusing to exclude an officer from the pension's reduction were quashed as arbitrary. Thus, many of the courts' decisions seemed to produce a more nuanced version of the past. The courts also had to deal with provisions whose conformity with the Constitution or international law was dubious, such as those involving collective

33 Sejm has passed more than 15 such resolutions in the last 4 years. See e.g. Resolution of Polish Sejm of 23 September 2016 on the Commemoration of the $40^{\text {th }}$ Anniversary of the Establishment of Workers' Defence Committee (Polish title: Uchwała Sejmu Rzeczypospolitej Polskiej z 23.09.2016 r. w sprawie uczczenia 40. rocznicy powstania Komitetu Obrony Robotników, M.P. poz. 968); Resolution of Polish Sejm of 16 December 2016 on the Commemoration of the $35^{\text {th }}$ Anniversary of Tragic December Events in "WUJEK" Coal Mine (Polish title: Uchwała Sejmu Rzeczypospolitej Polskiej z 16.12.2016 r. w sprawie uczczenia 35-tej rocznicy tragicznych wydarzeń grudniowych w Kopalni Węgla Kamiennego „WUJEK”, M.P. poz. 1239); Resolution of Polish Sejm of 21 April 2017 on the Commemoration of the 90 ${ }^{\text {th }}$ Anniversary of Tadeusz Mazowiecki's Birth (Polish title: Uchwała Sejmu Rzeczypospolitej Polskiej z 21.04.2017 r. w sprawie uczczenia 90. rocznicy urodzin Tadeusza Mazowieckiego, M.P. poz. 428).

34 Resolution of Polish Sejm of 12 December 2018 on the Commemoration of Victims of the Polish Martial Law (Polish title: Uchwała Sejmu Rzeczypospolitej Polskiej z 12.12.2018 r. w sprawie upamiętnienia ofiar stanu wojennego w Polsce, M.P. poz. 1248).

35 It is worth noting that both the Prohibition of the Promotion of Communism Act and most of the non-binding parliamentary resolutions - with a notable exception of the resolution of 24 November 2017 - were supported also by the majority of the opposition. The Civic Platform also supported the cleansing of the diplomatic service.

36 T.T. Koncewicz, On the Politics..., p. 289. 
accountability. Although two cases were referred to the CT, many courts decided to resolve cases themselves, either through reinterpretation of questionable provisions or refusal to apply them. This choice seems to be symptomatic of a general mistrust towards the CT, visible in a significant drop of cases referred to it by the courts ${ }^{37}$. In order to explain this change, I now turn to Poland's constitutional crisis.

\section{Poland's constitutional crisis and judicial reform from a transitional justice perspective}

\subsection{The crisis and its roots}

The years 2015-2019 in Poland were a time of a fundamental shift in the relations between the legislature and the executive on the one hand, and the judiciary on the other. The changes introduced by the government significantly altered the personal composition of the CT, the SC and the National Council of Judiciary (Polish: Krajowa Rada Sadownictwa, KRS), and expanded the powers of the Ministry of Justice in relation to ordinary courts. These changes were met with severe criticism from the opposition parties, NGOs, the Ombudsman, representative bodies of legal professions, and law schools - as well as with numerous public protests ${ }^{38}$. The actions of the administration also led to four harsh opinions issued by the Council of Europe's Venice Commission, three judgments of the Court of Justice of the European Union (CJEU) ${ }^{39}$, and to the decision of the European Commission to activate - for the first time in EU's history - the procedure provided for in Article 7 of the Treaty on European Union regarding a clear risk of a serious breach of the EU values by a Member State.

This negative attitude towards the changes introduced by the government is shared by the majority of Polish scholars who write on the subject. A representative example

37 After judge Julia Przyłębska (nominated to the CT by the Law and Justice) took the post of the President of the Tribunal in the end of 2016, courts have referred 59 cases to the CT by the time of writing of this article. In contrast, in years 2014-2016 this number was 236. Data available on CT webpage: http://trybunal.gov.pl/sprawy-w-trybunale, accessed on: 31 December 2019.

38 For a detailed account of the crisis see e.g.: A. Chmielarz-Grochal, J. Sułkowski. Appointment of Judges to the Constitutional Tribunal in 2015 as the Trigger Point for a Deep Constitutional Crisis in Poland, "Przegląd Konstytucyjny" 2018/2, pp. 91-119; A. Kustra, Poland's Constitutional Crisis. From Court-packing Agenda to Denial of Constitutional Court's Judgments, “Toruńskie Studia Polsko-Włoskie XII - Studi Polacco-Italiani Di Toruń” 2016/12, pp. 343-366; M. Matczak, Poland: From Paradigm to Pariah? Facts and Interpretations of Polish Constitutional Crisis, 12 March 2018, pp. 3-9, https://ssrn.com/abstract=3138541, accessed on: 15 November 2019; P. Radziewicz, P. Tuleja (eds.), Konstytucyjny spór o granice zmian organizacji i zasad działania Trybunatu Konstytucyjnego: czerwiec 2015 - marzec 2016 [Eng. A Constitutional Dispute Over the Limits of Organizational Changes and Principles of Operation of the Constitutional Tribunal: June 2015 - March 2016], Warszawa 2016; W. Sadurski, Poland's Constitutional Breakdown, Oxford 2019; G. Skąpska, The decline of liberal constitutionalism in East Central Europe, in: P. Vihalemm, A. Masso, S. Opermann (eds.), The Routledge International Handbook of European Social Transformations, London-New York 2018, pp. 130-145; J. Zajadło, Constitution-hostile Interpretation, "Przegląd Konstytucyjny" 2018/2, pp. 5-15; M. Ziółkowski, Constitutional Moment and the Polish Constitutional Crisis 2015-2018 (a few Critical Remarks), "Przegląd Konstytucyjny" 2018/4, pp. 76-106. Cf. B. Banaszak, The main principles of the reform of the Polish Constitutional Tribunal in December 2015: A comparative approach, in: A. Szmyt, B. Banaszak (eds.), Transformation of Law Systems in Central, Eastern and Southeastern Europe in 1989-2015. Liber Amicorum in Honorem Prof. Dr. Dres. H.C. Rainer Arnold, Gdańsk 2016, pp. 35-43; M. Muszyński, Anatomia „spisku”. Analiza prawna procesu wyboru sędziów Trybunatu Konstytucyjnego jesienia 2015 roku [Eng. Anatomy of the "Plot": Legal Analysis of the Election of Judges of the Constitutional Tribunal in the Autumn 2015], "Przegląd Sejmowy" 2017/2, pp. 75-103.

39 Judgment of the CJEU of 24 June 2019, European Commission v. Republic of Poland (C-619/18), ECLI:EU:C:2019:531; judgment of the CJEU of 5 November 2019, European Commission v. Republic of Poland (C-192/18), ECLI:EU:C:2019:924; judgment of the CJEU of 19 November 2019, K. v. Krajowa Rada Sadownictwa, and CP and DO v. Sąd Najwyższy (C-585/18, C-624/18 and C-625/18), ECLI:EU:C:2019:982. 
of this view may be the one put forward by Wojciech Sadurski in his 2019 book Poland's Constitutional Breakdown ${ }^{40}$. According to the author, the court-packing of the CT has transformed it from an effective counter-majoritarian protector of individual rights into an eager supporter of the parliamentary majority, thus "hollowing" the institution of its intended meaning ${ }^{41}$. The changes in the legislation regarding the SC, KRS and ordinary courts have left the judiciary highly vulnerable to political pressure and interference ${ }^{42}$. The process, Sadurski argues, can be referred to as "anti-constitutional populist backsliding":

It is anti-constitutional because it proceeds through statutory 'amendments' and outright breaches of the Constitution; it is populist because the ruling elite, while dismantling checks and balances, is actively fomenting societal support and mobilisation, and it is backsliding because it should be seen against the baseline of high democratic standards achieved in the recent past ${ }^{43}$.

This narrative of reversion and regression - shared by many other Polish authors - begs a question of what exactly caused this turn of events. Here, the answers differ significantly. Sadurski attributes the backsliding to three main factors: 1) anti-liberal, populist vision projected by Jarosław Kaczyński, the leader of the Law and Justice party; 2) resonance of this vision within the society, a large part of which was disenchanted with the liberal elite, fearful of the migration crisis, and tired of liberal constraints on the will of the majority; 3 ) fragility of democratic institutions caused by a lack of an entrenched political culture ${ }^{44}$. Marcin Matczak offers a different explanation of the crisis: 1) too lenient reckoning with the legacy of communism; 2) underdeveloped legal culture, allowing formalistic and isolated interpretations instead of holistic, principle-based ones; and 3) dissatisfaction with traditional liberal values as well as the need for group identification $^{45}$. In a similar vein, Grażyna Skąpska points inter alia to 1) lack of entrenched liberal democratic culture; 2) deteriorating popular support for Western-style liberal constitutionalism; 3) disappearance of constitutional consensus; 4) dominance of specific traditions of legal positivism; and 5) deflation of the meaning of liberalism in the capitalist economy - as the reasons for the decline ${ }^{46}$.

According to an alternative interpretation, the institutional change occurring in Poland is an example of a profound crisis of liberal constitutionalism and a turn towards political constitutionalism. Adam Czarnota claims that the liberal version of constitutionalism, which grants lawyers the sole right to establish the final meaning of constitutional provisions, was imposed on Poland in 1989 by the elites (including legal ones) which - having no regard for the local context - in a post-colonial manner copied institutional solutions developed in the West. For Czarnota the current crisis has a "democratic, emancipatory potential": he interprets the changes introduced by the government as a search for Poland's own constitutional identity in which "a participatory democracy", the rule of “a political nation", and "'dejuridization' of the public

\footnotetext{
W. Sadurski, Poland's...

W. Sadurski, Poland's..., pp. 58-95.

W. Sadurski, Poland's..., pp. 96-131.

W. Sadurski, Poland's..., p. vi. More on the subject: pp. 14-34.

W. Sadurski, Poland's..., pp. 162-191.

M. Matczak, Poland..., pp. 9-21.

G. Skąpska, The decline..., pp. 141-143.
} 
domain" are being promoted ${ }^{47}$. The return to the political is also present in the explanation given by Adam Sulikowski. Drawing on the works of Chantal Mouffe and Ernesto Laclau, Sulikowski sees the crisis as a symptom of the inevitable clash between the two components of liberal democracy: a liberal and a democratic one. In a liberal version of democracy, judgments of constitutional courts, using a seemingly neutral narrative of legal argumentation, remove certain issues from democratic considerations. In such a case, radical parties refuse to accept the position that the judgments of the constitutional court leave them in and see the court as the Schmittian enemy itself. Thus, even if Sulikowski believes the crisis may be a chance to reshape the CT as a body whose decisions can be defended on a political ground as well, he is disillusioned with the populist, conservative shift and refuses to see it as an example of participatory democracy ${ }^{48}$.

\subsection{Transitional justice dimension}

One of the above explanations refers in part to the way Poland has dealt with the past. According to Matczak, the lack of harsh retribution towards those involved in the communist period, the deposition from power of the government of Jan Olszewski, which aimed at a swift lustration, and the absence of members of current administration among the forces which shaped Poland's Constitution all triggered the mistrust of the Law and Justice party towards the fundamental law. Therefore, Matczak claims, those currently in power see the Constitution as an impunity mechanism enacted in bad faith in order to shield the beneficiaries of communism from substantive justice using procedural justice as an excuse $^{49}$. This belief necessarily extends to the CT, which safeguards the Constitution ${ }^{50}$. The main reason for this mistrust seems to be the 2007 CT judgment on the Lustration Act, which found a significant part of the law unconstitutional due to its ambiguity. The Tribunal also restricted lustration to the public sphere and reiterated a narrow definition of collaboration with the communist secret service, covering only those whose contacts were conscious and involved real cooperation ${ }^{51}$. It was after that judgment that the term "legal impossibilism" was coined. The term was used by some, including Law and Justice party leaders, to describe rigorous constitutional constraints on the will of the parliamentary majority, allegedly preventing it from enacting necessary reforms ${ }^{52}$.

47 A. Czarnota, Populist Constitutionalism or New Constitutionalism, "Krytyka Prawa" 2019/1, pp. 43-55. Quotes: p. 54. See also: M. Stambulski, A. Czarnota, The Janus Face of Constitutionalism, "Krytyka Prawa" 2019/1, pp. 18-26.

48 See e.g.: A. Sulikowski, Trybunat Konstytucyjny a polityczność. O konsekwencjach upadku pewnego mitu [Eng. The Constitutional Tribunal and Politicality. On the Consequences of Dispelling a Myth], "Państwo i Prawo" 2016/4, pp. 3-14; A. Sulikowski, Konstytucjonalizm wobec ,zemsty postmodernizmu” [Eng. Constitutionalism and the "Revenge of Postmodernism”], "Przegląd Prawa i Administracji” 2017/110, pp. 95-106.

49 M. Matczak, Poland..., pp. 9-12.

50 In one of his 2015 speeches Jarosław Kaczyński claimed that those who held power in Poland before the transition used political transformation to acquire property and privileges, and argued the CT "is supposed to be a redoubt defending this system, [defending] what was bad and shameful during these 26 years". Jarostaw Kaczyński na zakończenie Marszu Wolności i Solidarności: "Chca nam uniemożliwić przebudowę Polski!” [Eng. Jarostaw Kaczyński at the End of Freedom and Solidarity March: "They Want to Stop Us From Rebuilding Poland!'], wpolityce.pl, 13.12.2015 r., https:// tinyurl.com/y7774j89, accessed on: 18 April 2020. For an in-depth analysis of Kaczyński's speeches as an enterprise in politics of memory and community bulding see: W.J. Paluchowski, K. Podemski, Mowy miesięcznicowe Jarostawa Kaczyńskiego jako spektakl wtadzy [Eng. Jarostaw Kaczyński's 'Monthly Speeches' as a Spectacle of Power], "Ruch Prawniczy, Ekonomiczny i Socjologiczny” 2019/4, pp. 253-268.

51 Judgment of the CT of 11 May 2007 (K 2/07).

52 More on the term: M. Safjan, Wyzwania dla państwa prawa [Eng. Challenges for a Rule-of-Law State], Warszawa 2007, pp. 66-70; J. Zajadło, Pojęcie „imposybilizm prawny” a polityczność prawa i prawoznawstwa [Eng. The Notion of 'Legal Impossibilism' and the Political Nature of the Law and Legal Science], "Państwo i Prawo" 2017/3, pp. 17-30. 
The tension between substantive and procedural justice was also evident in the new SC Act proposed by Law and Justice MPs in July $2017^{53}$. The statute, which provided for the removal of all SC judges save the ones explicitly specified by the Minister of Justice, was in the end vetoed by the President of the Republic after mass public protests ${ }^{54}$. From a transitional justice perspective, the new regulation proposed in Article 1(2) of the statute seemed especially important. It vested the SC with the duty to safeguard not only the rule of law but also social justice. According to the official statement of purpose accompanying the bill, SC judgments should not only be consistent with formal requirements of the rule of law, but also with its substantive aspect. Yet, as the drafters claimed, "in the domestic legal system there are now many judgments which are formally legally appropriate, but which are far from being just" ${ }^{\prime 5}$. The statement of purpose provided a list of eleven judgments which the MPs deemed especially unfair: seven of them concerned transitional justice, including five regarding lustration. The lustration rulings included: 1) the judgment in which the SC reopened the proceedings, quashed the final judgment which declared the lustration statement to be false and discontinued the case because the immunity of the accused judge had not been lifted ${ }^{56} ; 2$ ) the judgment in which the SC ruled that under the Lustration Act service in reconnaissance army units could be regarded as duty in units of communist security service only if their actions included the suppression of rights listed in the preamble to the Act ${ }^{57} ; 3$ ) the judgments in which the SC assessed - wrongly, according to the drafters - that a false lustration statement was provided under the threat of exposure to foreign intelligence ${ }^{58}$ or 4) due to justifiable mistake ${ }^{59}$; 5) the ruling in which the $\mathrm{SC}$ refused to accept a cassation appeal filed by the General Public Prosecutor to the disadvantage of the accused, claiming that it was entered after the final date ${ }^{60}$. Two other transitional justice decisions included: 6) the resolution stating that the 1999 statute setting the year 1990 as a starting point for the running of a prolonged period of limitation of communist crimes could not reopen the running of limitation periods which had already expired ${ }^{61}$, and 7) the notorious SC resolution I KZP 37/07, in which the Court barred criminal proceedings against judges who retroactively applied criminal sanctions during the 1981 martial law. In this last case the SC claimed that the judges were obliged to enforce retroactive legislation due

53 See: Poselski projekt ustawy o Sądzie Najwyższym. Druk nr 1727, VIII kadencja Sejmu [Eng. Supreme Court Act MPs' Bill. Form No. 1727, 8th Term of Sejm], http://www.sejm.gov.pl/sejm8.nsf/druk.xsp?nr=1727, accessed on: 25 November 2019.

54 See also: M. Smolak, Kultura wtadzy i kultura uzasadniania w ujęciu Davida Dyzenhausa jako kategorie analizy proponowanych zmian w ustawie o Sądzie Najwyższym [Eng. Employing David Dyzenhaus' Conception of the Culture of Authority and the Culture of Justification for Analysing Changes Proposed by the Act on the Supreme Court], "Ruch Prawniczy, Ekonomiczny i Socjologiczny" 2017/4, pp. 19-30. Available in English at: https://pressto.amu.edu.pl/index. php/rpeis/article/view/11745/11961, accessed on: 2 December 2019.

55 Poselski projekt ustawy o Sądzie..., p. 84.

56 Judgment of the SC of 26 April 2016 (IV KO 98/15), LEX No. 2023794. In the judgment of the CT of 2 April 2015 (P 31/12), OTK-A 2015/4, item 44, the provision which allowed for the lustration process to proceed without lifting the immunity of a judge was found unconstitutional. This caused the reopening of lustration cases in which immunity was not lifted, the quashing of judgments, and the discontinuation of proceedings.

57 Decision of the SC of 5 May 2016 (II KK 4/16), LEX No. 2057617.

58 Decision of the SC of 20 March 2013 (II KK 230/12), LEX No. 1294447.

59 Decision of the SC of 10 July 2013 (II KK 347/12), unpublished.

60 Decision of the SC of 18 January 2012 (V KK 329/11), OSNKW 2012/3, item 32. The court held that such a cassation appeal needs to be filed no later than 6 months from the date on which the ruling became final, in accordance with article 524(3) of the Code of Criminal Procedure (CCP) (Polish title: Ustawa z 6.06.1997 r. - Kodeks postępowania karnego, tekst jedn.: Dz. U. z 2019 r. poz. 1460 ze zm.) and not within one year, as stipulated in article 21b(8) of the Lustration Act. The CCP was amended in 2017, extending the period to one year.

${ }_{61}$ Resolution of the SC of 25 May 2010 (I KZP 5/10), OSNKW 2010/7, poz. 55. 
to the features of communist legal system: lack of the lex retro non agit principle in the 1952 Polish Constitution ${ }^{62}$, the absence of constitutional review, and the uncertainty regarding the possibility of direct application of international treaties ${ }^{63}$. These and four other judgments made the drafters proclaim that the inclusion of Article 1(2) in the SC Act was meant to provide the citizens with "a sense of basic justice" ${ }^{64}$, allegedly violated by the SC's judgments.

Even though the President vetoed the bill, in September he proposed his own regulation, not much different from the one he refused to sign. The statement of purpose of the bill also contrasted formal justice with substantive justice ${ }^{65}$. In this vein, the Supreme Court Act $^{66}$ also introduced an extraordinary appeal that could be filed against any judgment that became final after 17 October 1997, the day when the Constitution went into force. The appeal can be filed if a judgment violated the principles of democratic rule of law and social justice - as well as infringed constitutional rights, or was based on an obvious error of law or fact ${ }^{67}$.

What is more, Article 111 of the SC Act also provided for a forcible retirement of all judges over 65 years of age, unless their motion for a prolonged service was granted by the President. In the end, the purge was not implemented due to a 2018 order of CJEU's Vice-President ${ }^{68}$ and the provision itself was repealed in 2019. Still, the analysis of the official reasons behind it remains instructive. According to the statement of purpose, even though in 1990 the SC was purged, some of the judges appointed to the $\mathrm{SC}$ in the following years allegedly had links with the communist party. The statement also blamed the CT and the SC for watering down lustration regulations and accused the legal professionals who had opposed harsher transitional justice measures of acting in their own vested interest. The drafters claimed that the only way to overcome such a legacy was through a purge based on age ${ }^{69}$. Additionally, as noted above, the SC Act also provided for the removal of judges who had worked for or collaborated with the communist security service ${ }^{70}$. This last provision is still in force.

The narrative employed by the government and the parliamentary majority during the debates on the SC bills also in part referred to reckoning with the communist past. Even though the sponsor of the July 2017 SC bill denied it was conceived as a decommunization measure ${ }^{71}$, the Minister of Justice Zbigniew Ziobro supported the bill claiming inter alia that the judiciary had never removed communist judges from its ranks, and that the SC was a court "of a communist pedigree", whose I KZP 37/07 resolution was motivated by "corporate solidarity and a desire to defend a certain post-communist

62 Constitution of the Polish People's Republic of 22 July 1952 (Polish title: Konstytucja Polskiej Rzeczypospolitej Ludowej uchwalona przez Sejm Ustawodawczy w dniu 22 lipca 1952 r., Dz. U. Nr 33, poz. 232 ze zm.).

63 Resolution of the SC of 20 December 2007 (I KZP 37/07), OSNKW 2007/12, item 86.

64 Poselski projekt ustawy o Sądzie..., p. 88.

65 Przedstawiony przez Prezydenta Rzeczypospolitej Polskiej projekt ustawy o Sadzie Najwyższym. Uzasadnienie. Druk nr 2003, VIII kadencja Sejmu [Eng. Supreme Court Act President's Bill. Statement of Purpose. Form No. 2003, 8th Term of Sejm], pp. 2, 5-8, http://www.sejm.gov.pl/sejm8.nsf/druk.xsp?nr=2003, accessed on: 25 November 2019.

${ }_{66}$ Act of 8 December 2017 on the Supreme Court (Polish title: Ustawa z 8.12.2017 r. o Sądzie Najwyższym, tekst jedn.: Dz. U. z 2019 r. poz. 825 ze zm.).

67 Articles 89 and 115 of the Supreme Court Act.

68 Order of the Vice-President of the CJEU of 19 October 2018, European Commission v. Republic of Poland (C-619/18), ECLI:EU:C:2018:852.

69 Przedstawiony przez Prezydenta..., pp. 2-3.

70 Article 36 of the Supreme Court Act.

71 Speech by Andrzej Matusiewicz MP (Law and Justice): Sprawozdanie stenograficzne z 46. posiedzenia Sejmu VIII kadencji [Eng. Minutes from 46. Session of 8th Term of Sejm], 18 July 2017, p. 119, https://tinyurl.com/SejmVIII46, accessed on: 18 April 2020. 
milieu"72. Another Law and Justice MP, Jan Kilian, claimed afterwards that passing the law was a "farewell to communism or to remains of post-communism" during the debate after which the 2017 SC Act was passed, the President's representative remarked that 15 of the then SC judges had been members of the communist party before $1989^{74}$. No evidence was produced to support these claims. Yet, the sole fact that the above arguments were raised shows that the government's actions were perceived as having a decommunization dimension by at least some of their supporters.

Thus, there appear to be two interconnected retrospective motivations behind the judicial reform. On a legal plane, frustration is evident with the jurisprudence of the CT and the SC, which is believed to be an obstacle on the way to achieve what the parliamentary majority sees as justice. The extraordinary appeal seems to be a measure designed to overcome this acquis. On an individual level, the changes in the composition of the $\mathrm{CT}$ and the appointment of new judges to the SC, as well as the planned purge of the latter, all seem to be aimed at the removal of judges who, according to the government, either have links with the communist past or, at best, are too lenient for those who have such connections. From this perspective, new judicial appointments can be perceived as a way to promote government policies, including the transitional justice agenda. Thus, the crisis clearly has a transitional justice dimension.

\section{The sincerity principle and the 2017 Supreme Court Act}

The constitutionality of many of the provisions described above is doubtful at best. Yet, here I would like to concentrate on a somewhat different question. Are the transitional justice motives presented in the statement of purpose of the 2017 Supreme Court Act genuine, or - as some claim - are they simply a rationalization of hidden political motives? In other words: is the statute in question imitative ${ }^{75}$ ?

In order to answer this question, I first assess the provisions of the act in the light of the Rawlsian principle of sincerity. I also present doubts regarding the honesty of motives behind the planned purge of the SC and the conditions under which these motives can be deemed genuine. Next, using the conclusions from the overview of transitional justice instruments provided in the second part the paper, I present arguments in favour of treating the motives as genuine. Finally, I claim that this interpretation allows to see the government actions related to the $\mathrm{SC}$ as a part of a broader transitional justice agenda, which due to the use of collective responsibility is irreconcilable with the rule of law.

\subsection{Transitional justice motives and conditions of their sincerity}

According to Wojciech Ciszewski, the Rawlsian public reason offers three criteria for the legitimacy of political actions: the principle of acceptability, of transparency, and of

72 Sprawozdanie stenograficzne z 46. posiedzenia..., 18 July 2017, p. 51.

73 Sprawozdanie stenograficzne z 46. posiedzenia..., 20 July 2017, p. 427, https://tinyurl.com/SejmVIII46a, accessed on: 18 April 2020.

74 Speech by Anna Surówka-Pasek (President's Office): Sprawozdanie stenograficzne z 52. posiedzenia Sejmu VIII kadencji [Eng. Minutes from 52. Session of 8th Term of Sejm], 22 November 2017, p. 123, https://tinyurl.com/SejmVIII52, accessed on: 18 April 2020.

75 See: M. Smolak, Ustawy imitacyjne [Eng. Imitative Statutes], "Ruch Prawniczy, Ekonomiczny i Socjologiczny" 2016/4, pp. 31-39. Available in English at: https://pressto.amu.edu.pl/index.php/rpeis/article/view/6839/6836, accessed on: 2 December 2019. 
sincerity ${ }^{76}$. The sincerity principle, which interests me here, means that there is "consistency between the reasons to which decision-makers officially refer and the reasons why they actually take action"77. This condition has to be met from an external perspective as well: the action is therefore legitimate if one can "rationally come to the conclusion that the considerations that have been officially indicated as its justification (and not some other reasons) are the best explanation for making that decision" 78 . Ciszewski also notes that Eric MacGilvray proposes two methods for such an evaluation. Firstly, according to the available data the action has to lead in normal circumstances to the consequences publicly offered as its explanation. Secondly, the principle of sincerity is infringed if the alleged motives should also trigger other actions which the decision-makers refuse to take ${ }^{79}$. To this I would like to add another method: even if the goals offered for an action are indeed one of its consequences, one may also doubt the honesty of an explanation if the methods are highly disproportionate, especially if the goal could be achieved by different, less invasive means.

In case of the extraordinary appeal, introduced by the 2017 Supreme Court Act, I am convinced that the sincerity principle has been met. The appeal is presented as an instrument of achieving socially acceptable justice, in contrast to a mere procedural one which the previous SC's judgments allegedly represented. This goal may indeed be achieved: even though the provision is bound to infringe upon legal certainty, it explicitly orders the SC to include social justice in its deliberations. Second, an overview of Law and Justice party transitional justice initiatives, especially the reduction of pensions of communist security service officials, seems to support the view that social perception of justice is an important value for the government. Finally, with the ne bis in idem principle being one of cornerstones of Polish legal system, there seems to be no other way in which the said goal could be achieved.

There are at least two reasons to doubt whether the arguments behind the planned purge of the SC were genuine as well. Firstly, only a small minority of SC judges had any links with pre-1989 proceedings against the opposition movement, such as the trials for the offences committed under the martial law. There has also been no attempt on the side of the government to individually assess whether their judgments suppressed the members of the opposition - or, through their leniency, were in fact a way to shield them from harsher prosecution ${ }^{80}$. Instead of individualised vetting, the administration opted for a purge based on age, even though it expressly acknowledged that such a purge would also cover judges who had belonged to anti-communist opposition and always supported democratic values ${ }^{81}$. Thus, the solution is so disproportionate that it casts reasonable doubt on the honesty of proposal. Secondly, a subsequent nomination of

76 W. Ciszewski, Rozum publiczny w praktyce - kwestia legitymacji moralnej wniosku grupy postów o stwierdzenie niekonstytucyjności przestanki aborcyjnej [Eng. Public Reason in Practice: The Moral Legitimacy of the Constitutional Complaint Lodged by Polish MPs Challenging the Constitutionality of the Abortion Law], "Ruch Prawniczy, Ekonomiczny i Socjologiczny" 2018/3, pp. 18-21. Available in English at: https://pressto.amu.edu.pl/ index.php/rpeis/article/ view/16496/19312, accessed on: 2 December 2019. Below, I refer to the English version of the text.

77 W. Ciszewski, Public Reason..., p. 20.

78 W. Ciszewski, Public Reason..., p. 21.

79 W. Ciszewski, Public Reason..., p. 21.

${ }^{80}$ Although the biographies of SC judges were much debated in Polish media, no serious incriminating evidence of politically motivated judgments was in fact revealed. See e.g.: Premier o "haniebnych wyrokach". Ilu sędziów Sądu Najwyższego orzekało $w$ stanie wojennym? [Eng. The Prime Minister on "Shameful Judgments". How Many Supreme Court Judges Adjudicated During the Martial Law?], TVN24.pl, 9 July 2018, https://tinyurl.com/wxtda28, accessed on: 2 December 2019.

81 Przedstawiony przez Prezydenta..., p. 2. 
a former martial law prosecutor for a CT judge, even if the claims of his impeccable conduct during that time are true, seems incoherent with a collective purge the SC Act proposed.

Yet, I believe there is an explanation under which the sincerity principle can be fulfilled. Let us assume that one believes that the goal can sometimes justify the means and that rule of law must sometimes yield to other values. In such a case, one can consider the indiscriminate purge of SC judges to be a necessary means to achieve desirable goals, including harsher judgments in cases related to transitional justice, provided that one also regards the principle of individual responsibility, one of the main components of the rule of law, as an insurmountable obstacle to achieving justice. In other words: if one believes that instruments acceptable under the rule of law have failed in the past and will fail in the future, one may decide to resort to measures outside this spectrum, such as collective responsibility. From this perspective, in order to secure effective process, the individualization of responsibility must become an exception to collective measures, a favour granted only in extraordinary situations.

\subsection{Three arguments in favour of the interpretation}

I am aware that the interpretation presented above does not prove that the explanation of the purge as a simple power grab is invalid. It is still a possible one, especially in light of the expansion of powers of the government in relation to ordinary courts. In fact, multiple motivations are possible. But I believe that - if one takes into account government's transitional justice initiatives presented above - my interpretation is coherent enough to regard reckoning with the past at least as an important co-motive. There are three arguments in favour of this claim.

Firstly, the interpretation of the planned purge of the SC judges as a decommunization policy is in line with the strong anti-communist views held by the parliamentary majority. As noted above, these views were expressed most vividly in non-binding parliamentary resolutions. Yet, they were also present in other transitional justice measures: cleansing the public sphere of communist symbols, reduction of pensions, and the new lustration model.

Secondly, the statement of purpose of the SC Act, admitting that the purge will affect some honourable judges, states that "currently it is difficult to propose a different objective vetting criteria other than the ones related to age or cooperation with the communist security service". It also mentions "with regret" SC resolution I KZP 37/07 (one that barred individual responsibility for judges who applied retroactive criminal sanctions during the martial law) $)^{82}$. Thus, the statement supports the view that the government believed the collective responsibility to be the only way to achieve its goals. This is also consistent with government actions in the transitional justice sphere, as collective responsibility was present both in the amendments to the Uniformed Services Pensions Act and in the remodelling of lustration to introduce general bans on holding certain public offices. When it comes to cleansing the public sphere of communist symbols, government-appointed voivodes and the IPN also supported a broader purge. It was only when the courts started to consider factors such as public perception of a name or the intentions of a local council that the assessment became more individualised.

82 Both quotes: Przedstawiony przez Prezydenta..., p. 2. 
Thus, not only did the government explicitly refer to collective responsibility in the statement of purpose of the SC Act, but it also repeatedly relied on it in the transitional justice domain.

Thirdly, the government seems to accept the view that individualization can only be an exception to collective responsibility. This appears to be the rationale not only behind Article 111 of the SC Act, which gave the President the right to grant a SC judge's motion to remain in service after retirement age, but also behind Article 8a of the Uniformed Services Pensions Act, which allowed for an exemption from pension reduction. Thus, the explanation is coherent with other retrospective measures introduced by the administration. In fact, it may also explain why certain exceptions (including appointments to important state positions) can be made for those who distinguished themselves in the present service for the government, despite their pre-transitional record.

\subsection{The problem of collective responsibility}

Of course, even if motives for an action are sincere, it does not necessarily mean that the action is also reasonable or justifiable. Thus, even if the government's motives are deemed honest, one may easily reject its actions as unreasonable (claiming e.g. that there are, in fact, no SC judges with links to the communism period meaningful enough to merit any attention 30 years after the transition) or unjustifiable in a liberal democracy. In fact, I claim that if the presented interpretation is correct, the sincerity of the government motives actually highlights the fact that its goals and measures are simply irreconcilable with the principle of individual responsibility and with the rule of law as it is understood today. Only if one is to accept that the government actions are motivated by its perception of justice (unacceptable though it may be), and therefore are more than a power grab, and only if one sees the planned purge of the SC judges as a retroactive sanction for their alleged links with communism or for their previous judgments - or for the links and verdicts of their colleagues - is it possible to see these actions as a part of a bigger transitional justice enterprise based on collective responsibility. From this point of view, the planned purge of the SC becomes the most prominent example of a series of transitional justice measures whose collective character makes them highly problematic from the perspective of the rule of law.

Thus, in the end the constitutional crisis presents itself as a conflict between procedural justice and substantive justice. On a favourable interpretation, this is a symptom of the tension between the rule of law and its procedural requirements on one hand, and the deep need for justice to be done on the other. From a more critical point of view, which I explored above, it may be regarded as a choice between a system where citizens bear rights that can be restricted only due to their individual wrongdoing, and a system where people are mere subjects to whom the government may grant a favour of a more individualized approach.

\section{Conclusions}

Between 2015 and 2019, Polish transitional justice initiatives included coherent, anticommunist politics of memory present most vividly in non-binding parliamentary resolutions and in the Prohibition of the Promotion of Communism Act, and a turn towards more radical measures, introduced in the amendments to the Uniformed Services 
Pensions Act and in the lustration regulations. This met with a reluctant response from the courts. Their judgments restricted the scope of legal regulation of memory and mitigated some of the outcomes of the legislation. Instead of referring constitutionally problematic statutes to the $\mathrm{CT}$, the courts often decided the cases themselves, which can be seen as yet another symptom of the constitutional crisis. Above, I have argued that the crisis has also a transitional justice dimension and can be regarded as a symptom of the tension between the rule of law, the procedural justice, and the principle of individual responsibility on the one hand - and, on the other, the desire to fulfil the government's perceptions of justice, which due to the use of collective responsibility leads to actions that violate those values.

In the field of transitional justice this tension is well known. Many authors stress that for procedural reasons in some cases justice simply cannot be done: witnesses may be dead, documents destroyed, and former officials of the regime may be unwilling to cooperate. Nevertheless, most scholars share the belief that this in no way justifies exceptions to the standards of fair trial, such as individual responsibility. As Juan E. Méndez puts it: "Much as it may hurt us to see known criminals go free, it is more important that we uphold fundamental principles of human rights - even in favor of those who once trampled on them - than in meting out well-deserved punishment to possible offenders" ${ }^{83}$. Yet, it is wise to remember that this belief does not have to be shared by the citizens themselves who - as in a famous quote from East German dissident Bärbel Bohley - may want justice, but get the rule of law instead ${ }^{84}$.

The influence of lenient transitional justice policy on Poland's constitutional crisis should not be overestimated. There are other, perhaps more profound reasons for the constitutional backsliding that the country has experienced in the last four years. Yet, it is evident that the crisis also has a transitional justice dimension: in this paper, I have argued that the government's desire for a harsher decommunization policy is a likely co-motive of its actions against the judiciary. Thus, if one is to draw a lesson from the Polish experience, it seems that even though the most severe ways of reckoning with past wrongs are inconsistent with the rule of law, an approach that is too lenient can fuel radical solutions and thus in the end politically endanger the existence of the liberal democracy itself.

\title{
Transitional Justice and the Constitutional Crisis: The Case of Poland (2015-2019)
}

\begin{abstract}
During the last four years the situation in Poland has been a matter of interest to the worldwide legal community mostly due to the constitutional crisis. Yet, the years 2015-2019 were also a time of a revival of transitional justice measures, such as cleansing the public sphere of communist symbols, remodelling of lustration law, and further reduction of pensions of communist secret service employees and officers. In this paper I argue that these spheres are interconnected and that Poland's constitutional crisis has a transitional justice dimension. I start with an overview of retrospective instruments dealing with the communist past introduced in the last four years. Next, I turn to the constitutional crisis itself, discussing its possible explanations and transitional justice aspects. In the end I claim that the dramatic

83 J.E. Méndez, In Defense of Transitional Justice, in: A.J. McAdams (ed.), Transitional Justice and the Rule of Law in New Democracies, Notre Dame 1997, p. 12.

84 N.J. Kritz, The Dilemmas of Transitional Justice, in: N.J. Kritz (ed.), Transitional Justice: How Emerging Democracies Reckon with Former Regimes, Volume I: General Considerations, Washington 1995, p. xxiv.
\end{abstract}


constitutional backsliding that Poland has recently experienced can be explained not only as a power grab, but also as a result of the tension between the rule of law and the principle of individual responsibility on one hand - and the resort to collective accountability in an attempt to get what the government sees as justice on the other.

Keywords: transitional justice, lustration, decommunization, Poland's constitutional crisis, Polish Supreme Court, rule of law, sincerity principle 


\section{BIBLIOGRAFIA / REFERENCES:}

Banaszak, B. (2016). The main principles of the reform of the Polish Constitutional Tribunal in December 2015: A comparative approach. In A. Szmyt, B. Banaszak (eds.), Transformation of Law Systems in Central, Eastern and Southeastern Europe in 1989-2015. Liber Amicorum in Honorem Prof. Dr. Dres. H.C. Rainer Arnold (pp. 35-43). Gdańsk: Gdańsk University Press.

Banaszkiewicz, B. (2003). Rozrachunek z przeszłością komunistyczną w polskim ustawodawstwie i orzecznictwie Trybunału Konstytucyjnego. Ius et Lex 1, 441-486.

Barsalou, J., Baxter, V. (2007). The Urge to Remember. The Role of Memorials in Social Reconstruction and Transitional Justice. Washington: United States Institute of Peace. Retrieved from: https://www.usip.org/sites/default/files/srs5.pdf

Chmielarz-Grochal, A., Sułkowski J. (2018). Appointment of Judges to the Constitutional Tribunal in 2015 as the Trigger Point for a Deep Constitutional Crisis in Poland. Przeglad Konstytucyjny 2, 91-119.

Ciobanu, M., Krotoszyński, M. (forthcoming). Lustration Court (Poland). In L. Stan, N. Nedelsky (eds.), Encyclopedia of Transitional Justice, Vol. 3, $2^{\text {nd }}$ ed. Cambridge: Cambridge University Press.

Ciszewski, W. (2018). Rozum publiczny w praktyce - kwestia legitymacji moralnej wniosku grupy posłów o stwierdzenie niekonstytucyjności przesłanki aborcyjnej. Ruch Prawniczy, Ekonomiczny i Socjologiczny 3, 18-21.

Czarnota, A. (2007). The Politics of the Lustration Law in Poland, 1989-2006. In: A. Mayer-Rieckh, P. de Greiff (eds.), Justice as Prevention. Vetting Public Employees in Transitional Societies (pp. 222-258). New York: Social Science Research Council.

Czarnota, A. (2019). Populist Constitutionalism or New Constitutionalism. Krytyka Prawa 1, 43-55.

Elser, J. (2004). Closing the Books: Transitional Justice in Historical Perspective. Cambridge: Cambridge University Press.

Grabarczyk, M. (2019). Uniformed Services Pension Amendment Acts in Poland as a Part of State Politics of Memory. Archiwum Filozofii Prawa i Filozofii Społeczne 3, pp. 67-80.

Koncewicz, T.T. (2017). On the Politics of Resentment, Mis-memory, and Constitutional Fidelity: The Demise of the Polish Overlapping Consensus? (pp. 263-290) In: U. Belavusau, A. GliszczyńskaGrabias (eds.), Law and Memory: Towards Legal Governance of History. Cambridge: Cambridge University Press.

Kritz, N.J. (1995). The Dilemmas of Transitional Justice. In: N.J. Kritz (ed.), Transitional Justice: How Emerging Democracies Reckon with Former Regimes, Volume I: General Considerations, Washington: United States Institute of Peace.

Krotoszyński, M. (2014). Polish Lustration and the Models of Transitional Justice. Adam Mickiewicz University Law Review 3, 199-211.

Krotoszyński, M. (2017). Modele sprawiedliwości tranzycyjnej. Poznań: Wydawnictwo Naukowe UAM.

Kustra, A. (2016). Poland's Constitutional Crisis. From Court-packing Agenda to Denial of Constitutional Court's Judgments. Toruńskie Studia Polsko-Włoskie XII - Studi Polacco-Italiani Di Toruń 12, 343-366.

Light, D., Young, C. (2015). Public Memory, Commemoration, and Transitional Justice: Reconfiguring the Past in Public Space (pp. 233-251). In: L. Stan, N. Nedelsky (eds.), Post-Communist Transitional Justice. Lessons from Twenty-Five Years of Experience. New York: Cambridge University Press. 
Małecki, M., Mikuli, P. (2018). The New Polish 'Memory Law': A Short Critical Analysis. DPCE Online 1, 279-284.

Matczak, M. (2018). Poland: From Paradigm to Pariah? Facts and Interpretations of Polish Constitutional Crisis. Retrieved from: https://ssrn.com/abstract=3138541.

Méndez, J.E. (1997). In Defense of Transitional Justice. In A.J. McAdams (ed.), Transitional Justice and the Rule of Law in New Democracies. Notre Dame: University of Notre Dame Press.

Młynarska-Sobaczewska, A. (2010). Autorytet państwa. Legitymizacyjne znaczenie prawa w państwie transformacji ustrojowej. Torun: TNOiK "Dom Organizatora".

Murphy, C. (2017). The Conceptual Foundations of Transitional Justice. Cambridge: Cambeidge University Press.

Muszyński, M. (2017). Anatomia „spisku”. Analiza prawna procesu wyboru sędziów Trybunału Konstytucyjnego jesienią 2015 roku. Przeglad Sejmowy 2, 75-103.

Nalepa, M., Krotoszyński, M. (forthcoming). Poland. In L. Stan, N. Nedelsky (eds.), Encyclopedia of Transitional Justice. Vol. 2, $2^{\text {nd }}$ ed. Cambridge: Cambridge University Press.

Paluchowski, W.J., Podemski, K. (2019). Mowy miesięcznicowe Jarosława Kaczyńskiego jako spektakl władzy. Ruch Prawniczy, Ekonomiczny i Socjologiczny 4, 253-268.

Radziewicz, P., Tuleja P. (eds.) (2016). Konstytucyjny spór o granice zmian organizacji i zasad działania Trybunatu Konstytucyjnego: czerwiec 2015 - marzec 2016. Warszawa: Wolters Kluwer.

Sadurski, W. (2019). Poland's Constitutional Breakdown. Oxford: Oxford University Press.

Safjan, M. (2007). Wyzwania dla państwa prawa. Warszawa: Wolters Kluwer.

Skąpska, G. (2018). The decline of liberal constitutionalism in East Central Europe. In P. Vihalemm, A. Masso, S. Opermann (eds.), The Routledge International Handbook of European Social Transformations (pp. 130-145). London-New York: Routledge.

Smolak, M. (2016). Ustawy imitacyjne. Ruch Prawniczy, Ekonomiczny i Socjologiczny 4, 31-39.

Smolak, M. (2017). Kultura władzy i kultura uzasadniania w ujęciu Davida Dyzenhausa jako kategorie analizy proponowanych zmian w ustawie o Sądzie Najwyższym. Ruch Prawniczy, Ekonomiczny i Socjologiczny 4, 19-30.

Stambulski, M., Czarnota, A. (2019). The Janus Face of Constitutionalism. Krytyka Prawa 1, 18-26.

Sulikowski, A. (2016). Trybunał Konstytucyjny a polityczność. O konsekwencjach upadku pewnego mitu. Państwo i Prawo 4, 3-14.

Sulikowski, A. (2017). Konstytucjonalizm wobec „zemsty postmodernizmu”. Przeglad Prawa $i$ Administracji 110, 95-106.

Teitel, R. (2000). Transitional Justice, New York: Oxford University Press.

Wójcik, A., Belavusau, U. (2018). Renaming Streets - A Key Element of Identity Politics. New Eastern Europe 3-4, 161-166.

Zajadło, J. (2017). Pojęcie „imposybilizm prawny” a polityczność prawa i prawoznawstwa. Państwo $i$ Prawo 3, 17-30.

Zajadło, J. (2018). Constitution-hostile Interpretation. Przegląd Konstytucyjny 2, 5-15.

Ziółkowski, M. (2018). Constitutional Moment and the Polish Constitutional Crisis 2015-2018 (a few Critical Remarks). Przeglad Konstytucyjny 4, 76-106. 